\title{
Effects of test mixture and commercial probiotic on broilers growth performance
}

\author{
Aida Kavazović ${ }^{*}$, Abdulah Gagić ${ }^{2}$, Emina Rešidbegović ${ }^{2}$, Teufik Goletić 2 , \\ Ćazim Crnkić1, Almira Softić ${ }^{3}$, Aida Kustura ${ }^{2}$, and Edin Šatrovićc \\ ${ }^{1}$ Department of Animal Nutrition, Veterinary Faculty Sarajevo, University of Sarajevo, \\ Bosnia and Herzegovina \\ ${ }^{2}$ Department of Avian Diseases and Management, Veterinary Faculty Sarajevo, University of Sarajevo, \\ Sarajevo, Bosnia and Herzegovina \\ ${ }^{3}$ Department of Animal Husbandry, Veterinary Faculty Sarajevo, University of Sarajevo, Sarajevo, \\ Bosnia and Herzegovina \\ ${ }^{4}$ Department of State and Forensic Veterinary Medicine, Veterinary Faculty Sarajevo, University of Sarajevo, \\ Sarajevo, Bosnia and Herzegovina
}

KAVAZOVIĆ, A., A. GAGIĆ, E. REŠIDBEGOVIĆ, T. GOLETIĆ, Ć. CRNKIĆ, A. SOFTIĆ, A. KUSTURA, E. ŚATROVIĆ: Effects of test mixture and commercial probiotic on broilers growth performance. Vet. arhiv 89, 873-883, 2019.

\section{ABSTRACT}

The objective of this study was to investigate the effects of test mixture or probiotic addition to drinking water on the growth performance of broiler chickens. A total of 240 one-day-old Cobb 500 chickens were distributed into three groups with eight replicates in each (10 chickens in each replicate). The control group of chickens $(\mathrm{C})$ were without treatment. The chickens in experimental group E1 were treated with the commercial probiotic Probios $^{\circledR}$ and the chickens in experimental group E2 were treated with the test mixture (Lactobacillus acidophilus culture, inactivated baker's yeast, C vitamin, lactose and glucose) prepared using the authors' own recipe. Treatments of chickens were conducted during the first three days of life and for three days using the chickens' vaccination drinking water. The experiment lasted for 42 days. Feed and water were offered ad libitum during the experiment. Body weight, daily feed intake, body weight gain, feed conversion ratio (FCR), carcass weight, carcass yield and European production index (EPI) were studied in this experiment. The addition of the experimental probiotic significantly increased $(\mathrm{P}<0.05)$ body weight gain at 21,35 and 42 days of age, however, the probiotic Probios ${ }^{\circledR}$ improved body weight gain over the same period without any significant difference compared to the control group. FCR was significantly improved at 21 and 35 days of age in both E1 and E2 groups, but at the end of fattening the FCR was not affected. Feed consumption was not influenced by the treatments. The results obtained indicate that carcass weight significantly increased $(\mathrm{P}<0.05)$ in the groups of chickens treated by the test mixture or probiotic. It was concluded that addition of test mixture or probiotic improved body weight gain, feed conversion ratio, carcass weight and EPI.

Key words: broiler chickens; test mixture; probiotic; growth performance; carcass

*Corresponding author:

Prof. Aida Kavazović, Department of Animal Nutrition, Veterinary Faculty Sarajevo, University of Sarajevo, Zmaja od Bosne 90 , 71000 Sarajevo, Bosnia and Herzegovina, Phone: +387 33729 121; Fax: +387 33650 435; E-mail: aida.kavazovic@vfs.unsa.ba 
A. Kavazović et al..: Effects of test mixture and commercial probiotic on broilers growth performance

\section{Introduction}

Probiotics are defined as live microorganisms which can confer health benefits for the host when administered in appropriate and regular quantities (FAO, 2009). The most widely used probiotic strains are of the genus Lactobacillus, which is also the dominant genus in the proximal intestine of chickens early in life. The natural adaptation of lactic acid bacteria to the intestinal environment and the lactic acid they produce has advantages for these organisms over other microorganisms used as probiotics (FULLER, 1999; JIN et al., 2000; TORRES-RODRIGUEZ et al., 2007; SALIM et al., 2013; SALEHIMANESH et al., 2016; GADDE et al., 2017).

The most common routes of administration of probiotic preparations are in feed and drinking water, but they may also be applied by spraying eggs or newly hatched chicks (FULLER, 1999). In poultry, probiotics are used after gastrointestinal infections and digestive disorders, in stress caused by environmental factors (high and low temperatures), during transportation to production facilities, after antibiotic therapy, as a part of preventive health care, for better utilization of feed and better production results (JIN et al., 2000; APATA, 2008; MAHFUZ et al., 2017).

Probiotics have a beneficial effect on growth performance and humoral immune response, and they leave no residues in meat which could have serious implications for consumer health (ECKERT et al., 2010; KAVAZOVIĆ et al., 2009; MANAFI et al., 2018). VICENTE et al. (2007) reported that the administration of probiotics containing Lactobacillus in a field trial increased body weight by $2.06 \%$, and improved feed conversion by $3.5 \%$ in the treated chickens. The results of several studies have shown that probiotics in broiler diets improve growth performance compared with the controls, being as effective as antibiotic growth promoters (DENLI et al., 2003; BAI et al., 2013). POURAKBARI et al. (2016) examined the effects of diet supplementation with increasing levels of a probiotic (Protexin), and concluded that probiotics in feed at $0.10 \mathrm{~g} / \mathrm{kg}$ or higher levels of supplementation improved body weight gain $(+12 \%)$ and feed conversion rate $(-5 \%)$ compared with the control, but there were no effects on carcass traits. In another study, the addition of different probiotics (Bactocell ${ }^{\mathbb{Q}}$ and Revitilyte-Plus ${ }^{\circledR}$ ) to broiler feed significantly improved body weight and feed conversion ratio (ABD-EL RAHMAN et al., 2012). After conducting two experiments, ONIFADE et al. (1999) found that the addition of S. cerevisiae to the diet improves growth and carcass weight, while reducing abdominal fat deposition. However, SALEHIMANESH et al. (2016) suggests that the addition of antibiotics and probiotics has no influence on growth performance of broilers, particularly in good hygiene conditions. The objective of this study was to investigate the effect of the addition of a commercial probiotic or test mixture (Lactobacillus acidophilus culture, inactivated baker's yeast, $\mathrm{C}$ vitamin, lactose and glucose) to drinking water, on the growth performance of broiler chickens. 
A. Kavazović et al.: Effects of test mixture and commercial probiotic on broilers growth performance

\section{Materials and methods}

A total of 240 one-day-old Cobb 500 chickens were weighed and randomly distributed into three groups (control - C and experimental groups - E1 and E2) with eight replicates (10 chicks in each replicate). The experiment lasted for 42 days. Chickens were reared in floor pens $(120 \times 80 \times 70 \mathrm{~cm})$ in an environmentally controlled room. Feed and water were provided ad libitum

The control group $(\mathrm{C})$ received water without treatment, experimental group E1 was treated with the commercial probiotic Probios ${ }^{\circledR}$ and experimental group E2 was treated with the test mixture. Probios ${ }^{\circledR}$ is a soluble powder for poultry produced by Chr. HANSEN A/S, Denmark, containing $1.1 \times 10^{8} \mathrm{CFU} * / \mathrm{g}$ Lactic Acid Bacteria (Lactobacillus acidophilus, Lactobacillus plantarum, Enterococcus faecium, Lactobacillus casei), sodium tiosulphate, dried whey, sodium silico aluminate. It was given through the drinking water at the manufacturer's recommended rate of $1 \mathrm{mg} / \mathrm{chicken}$ per treatment day. The test mixture contained two components prepared according to the authors' own recipe. The first component contained 5\% inactivated baker's yeast, $20 \%$ vitamin C, $4 \%$ lactose and $71 \%$ glucose as an inactive ingredient, and was administered in the drinking water in the amount of $0.3 \mathrm{~g} /$ chicken per treatment day. The second component, the Lactobacillus acidophilus culture, was isolated from acidophilus milk and applied as $1 \mathrm{~mL}$ of a 106 $C F U / \mathrm{mL}$ suspension per chicken per treatment day.

The treatments of the chickens were conducted during the first three days of life and for three days during the chickens' vaccination against Newcastle disease, Gumboro disease and Infectious Bronchitis (the day before, on the day of and the day after the vaccination). The chicks were vaccinated against Newcastle disease, Infectious Bursal Disease and Infectious Bronchitis on the 9th, 14th and 25th days of age, respectively. The vaccines were administered via the drinking water.

During the experiment, the chickens were fed with a starter diet up to 21 days, then a grower diet from 22 to 35 days, and a finisher diet from 36 to 42 days of age. The ingredient composition, calculated nutritive value and chemical analysis of the diets are presented in Table 1.

The body weight and feed consumption were recorded weekly. Body weight gain, feed consumption and feed conversion ratio were calculated at the end of the starter, grower and finisher periods for each treatment, at 21,35 and 42 days of age, respectively. The European Production Index (EPI), carcass weight and carcass yield were calculated at the end of the experiment.

The data obtained in this study were analysed statistically by Minitab 17 Statistical Software (Minitab, Inc. 2014). The results were processed by One-way ANOVA and the Tukey test was used to test the difference of mean values. Differences were considered 
A. Kavazović et al..: Effects of test mixture and commercial probiotic on broilers growth performance

significant when $\mathrm{P}<0.05$. The unit for statistical analysis was a replication within the treatment, with eight replications per treatment.

Table 1. Ingredient composition, calculated nutritive value and chemical analysis of diets (as-fed basis)

\begin{tabular}{|c|c|c|c|}
\hline Ingredients, \% & $\begin{array}{c}\text { Starter } \\
0 \text { to } 21 \text { day }\end{array}$ & $\begin{array}{c}\text { Grower } \\
22 \text { to } 35 \text { days }\end{array}$ & $\begin{array}{c}\text { Finisher } \\
36 \text { to } 42 \text { days }\end{array}$ \\
\hline Corn & 51.35 & 52.65 & 57.52 \\
\hline Wheat & 2.00 & 2.00 & 1.00 \\
\hline Soybean meal & 31.50 & 30.00 & 32.00 \\
\hline Fish meal & 7.00 & 6.50 & - \\
\hline Sunflower oil & 4.00 & 5.20 & 6.00 \\
\hline Limestone & 1.00 & 1.00 & 1.00 \\
\hline Dicalcium phosphate & 0.90 & 0.95 & 1.60 \\
\hline Salt & 0.20 & 0.20 & 0.30 \\
\hline L-lysine & 0.05 & - & 0.08 \\
\hline DL-metionin & 0.14 & 0.11 & - \\
\hline Premix 1,2 & $0.50^{1}$ & $0.50^{2}$ & $0.50^{2 *}$ \\
\hline \multicolumn{4}{|c|}{ Calculated nutritive value } \\
\hline Lysine, $\%$ & 1.41 & 1.30 & 1.14 \\
\hline Methionine, $\%$ & 0.61 & 0.57 & 0.52 \\
\hline \multicolumn{4}{|l|}{ Chemical analysis } \\
\hline Crude protein, $\%$ & 22.94 & 21.90 & 19.22 \\
\hline Crude fat, $\%$ & 6.28 & 7.30 & 8.00 \\
\hline Crude fiber, $\%$ & 3.10 & 3.01 & 3.13 \\
\hline Calcium, \% & 1.08 & 0.99 & 1.21 \\
\hline Phosphorus, \% & 0.69 & 0.65 & 0.71 \\
\hline $\mathrm{ME}, \mathrm{MJ} / \mathrm{kg}$ & 13.22 & 13.57 & 13.38 \\
\hline
\end{tabular}

${ }^{1}$ Premix (PT-S) provided the following per kg of diet: vitamin A $12000 \mathrm{IJ}$; vitamin D3 $2400 \mathrm{IJ}$; vitamin E 30 $\mathrm{mg}$; thiamine $1.5 \mathrm{mg}$; riboflavin $6 \mathrm{mg}$; nicotine amid $35 \mathrm{mg}$; calcium pantothenate $10 \mathrm{mg}$; pyridoxine $4 \mathrm{mg}$;

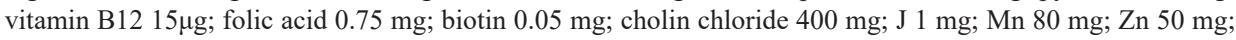
Co $0.1 \mathrm{mg}$; Fe $30 \mathrm{mg}$; Cu $5 \mathrm{mg}$; Se $0.15 \mathrm{mg}$.

${ }^{2}$ Premix (PT-F) provided the following per kg of diet: vitamin A $12000 \mathrm{IJ}$; vitamin D3 $2400 \mathrm{IJ}$; vitamin E $30 \mathrm{mg}$; thiamine $1.5 \mathrm{mg}$; riboflavin $6 \mathrm{mg}$; nicotine amid $35 \mathrm{mg}$; calcium pantothenate $10 \mathrm{mg}$; pyridoxine $4 \mathrm{mg}$; vitamin B12 $15 \mu \mathrm{g}$; folic acid $0.75 \mathrm{mg}$; biotin $0.05 \mathrm{mg}$; cholin chloride $400 \mathrm{mg}$; $1 \mathrm{mg}$; Mn 80 mg; Zn $50 \mathrm{mg}$; Co $0.1 \mathrm{mg}$; Fe $30 \mathrm{mg}$; Cu 5 mg; Se $0.15 \mathrm{mg}$.

* Premix (PT- F) no coccidiostats 
A. Kavazović et al.: Effects of test mixture and commercial probiotic on broilers growth performance

\section{Results and discussion}

Body weight (BW), body weight gain (BWG), feed consumption, FCR and EPI are presented in Table 2 . The BW of the one-day-old broiler chickens was not significantly different at the beginning of the experiment. At the end of the starter, grower and finisher periods the addition of the test mixture (E2 group) to the drinking water significantly increased $(\mathrm{P}<0.05)$ body weight and body weight gain compared with the group $\mathrm{C}$. However, the chickens in the group treated with the commercial probiotic Probios ${ }^{\circledR}$ (E1) achieved higher body weight and body weight gain than group C, but without any significant difference. A non-significant difference $(\mathrm{P}>0.05)$ for $\mathrm{BW}$ and $\mathrm{BWG}$ was found between groups E1 and E2.

Table 2. The effect of the test mixture or probiotic on the growth performance of broiler chickens

\begin{tabular}{|c|c|c|c|c|c|}
\hline Performance & $\mathrm{C}$ & $\mathrm{E}_{1}$ & $\mathrm{E}_{2}$ & SD & $P$ value \\
\hline \multicolumn{6}{|c|}{ Body weight (g) } \\
\hline 1 day & 42.7 & 42.7 & 42.5 & 0.20 & 0.052 \\
\hline 21 & $786.8^{\mathrm{b}}$ & $815.2^{\mathrm{ab}}$ & $819.6^{\mathrm{a}}$ & 25.01 & 0.032 \\
\hline 35 & $1878.9^{\mathrm{b}}$ & $1916.3^{\mathrm{ab}}$ & $1965.6^{\mathrm{a}}$ & 42.00 & 0.002 \\
\hline 42 & $2369.2^{\mathrm{b}}$ & $2413.8^{\mathrm{ab}}$ & $2423.6^{\mathrm{a}}$ & 38.60 & 0.024 \\
\hline \multicolumn{6}{|c|}{ Body weight gain (g) } \\
\hline $1-21$ & $744.1^{\mathrm{b}}$ & $772.5^{\mathrm{ab}}$ & $777.1^{\mathrm{a}}$ & 25.05 & 0.032 \\
\hline $1-35$ & $1836.2^{\mathrm{b}}$ & $1873.6^{\mathrm{ab}}$ & $1923.1^{\mathrm{a}}$ & 42.00 & 0.002 \\
\hline $1-42$ & $2326.5^{\mathrm{b}}$ & $2371.1^{\mathrm{ab}}$ & $2381.1^{\mathrm{a}}$ & 38.60 & 0.023 \\
\hline \multicolumn{6}{|c|}{ Feed consumption $(\mathrm{g})$} \\
\hline $1-21$ & 1098.6 & 1090.7 & 1096.2 & 32.70 & 0.886 \\
\hline $1-35$ & 3019.8 & 2997.7 & 3041.3 & 67.90 & 0.453 \\
\hline $1-42$ & 4099.4 & 4130.8 & 4154.3 & 57.10 & 0.180 \\
\hline \multicolumn{6}{|c|}{ Feed conversion ratio $(\mathrm{g} / \mathrm{g})$} \\
\hline $1-21$ & $1.48^{\mathrm{b}}$ & $1.41^{\mathrm{a}}$ & $1.41^{\mathrm{a}}$ & 0.04 & 0,008 \\
\hline $1-35$ & $1.65^{\mathrm{b}}$ & $1.60^{\mathrm{a}}$ & $1.58^{\mathrm{a}}$ & 0.03 & 0.002 \\
\hline $1-42$ & 1.76 & 1.74 & 1.75 & 0.02 & 0.155 \\
\hline \multicolumn{6}{|c|}{ European Production Index - EPI } \\
\hline $1-42$ & $320^{\mathrm{b}}$ & $330^{\mathrm{ab}}$ & $331^{\mathrm{a}}$ & 8.16 & 0.033 \\
\hline
\end{tabular}

At the end of fattening ( $42^{\text {nd }}$ day) it was noticeable that the addition of the test mixture and commercial probiotic had positively impacted the BW. Although the test mixture 
treatment of chickens was carried out according to the authors' own scheme, it was evident that the full effect was achieved in the second and final stage of the fattening, i.e. from the 21 st to the 42 nd day. It is therefore clear that the use of probiotics at the time when individuals were exposed to the greatest stress (during and after transport, during and after vaccinations) proved to be beneficial. ECKERT et al. (2010) found that intermittent application of a probiotic via water increased BW on day 15 and day 40 $(\mathrm{P}<0.05)$ compared to all other treatments (control, probiotic administered in feed and a phytogenic product). Many authors also reported that the application of probiotics over the entire period of fattening resulted in improved BWG (JIN et al, 2000; ABDELRAMAN et al., 2012; HRNČAR et al., 2014; MANAFI et al., 2018).

The positive effect of the $L$. acidophilus culture in the test mixture is in agreement with APATA, (2008), BOOSTANI et al. (2013) and TOGHYANI et al. (2015). Yoghurt and kefir contain mostly lactobacilli, as well as other useful bacteria that have positive health effects. Lactobacilli, as beneficial bacteria, have the ability to help the digestion of dietary proteins, carbohydrates and fats, and increase the absorption of nutrients (EDDENS, 2003; APATA, 2008). TORRES-RODRIGUEZ et al. (2007) reported that the use of Lactobacillus spp. and lactose, as in our research, resulted in improvement in the body weight of fattening turkeys. KAVAZOVIĆ et al. (2004) reported that the addition of inactivated yeast, vitamin $\mathrm{C}$, lactose and glucose to drinking water during fattening increased broiler performance. The combination of a L. acidophilus culture, different prebiotics, vitamins, bakery yeast or glucose has been reported to improve broilers' performance (VICENTE et al., 2007; KAVAZOVIĆ et al., 2009). The positive effect of inactivated baker's yeast (S. cerevisiae) could be primarily due to the high content of valuable biological components (proteins, vitamins B complex, enzymes, nucleic acids, minerals). Lactose was used as the prebiotic, because poultry cannot digest it, and it is therefore available to the microflora in the caecum. The fermentation of lactose in this way increases the production of lactic acid and volatile fatty acid, resulting in a considerable reduction in caecal $\mathrm{pH}$. Volatile fatty acids have a bactericidal and bacteriostatic effect that can reduce the colonization of entereopatogenic bacteria, and improve utilization of nutrients (CORRIER et al., 1990). However, several papers have reported that the supplementation of probiotics, prebiotic and synbiotics had no significant effects on broiler growth performance (NIKPIRAN et al., 2013; SALEHIMANESH et al., 2016). The cumulative feed consumption per chicken is presented in Table 2. On the basis of the results of the feed consumption, it is evident that the chickens in the control and the experimental groups consumed about the same amount of feed per chicken throughout the whole fattening period. These results agree with others (NAYEBPOR et al., 2007; BOOSTANI et al., 2013; POURAKBARI et al., 2016). 
A. Kavazović et al.: Effects of test mixture and commercial probiotic on broilers growth performance

In both experimental groups, FCR was significantly better $(\mathrm{P}<0.05)$ than in group $\mathrm{C}$ at the end of the starter and grower periods. These results match those obtained by JIN et al. (2000), who observed that broilers fed diets containing a mixture of 12 Lactobacillus strains had better BWG from days 22 to 42 of age, and lower FCR during the starter and grower periods. The significant increase in BWG in group E2 indicates the positive effect of the test mixture on the production parameters in broiler chickens. KAVAZOVIĆ et al. (2009) found that the addition of the same test mixture and commercial probiotic $\left(\right.$ Probios $^{\mathbb{B}}$ ) to drinking water increased BW, BWG and improved FCR in broilers at the end of fattening with no significance. TALEBI and KHADEMI (2011) reported that the combination of glucose with vitamin $\mathrm{C}$ in drinking water resulted in higher body weight, feed efficiency and lower feed conversion ratio $(\mathrm{P}<0.05)$ at the finisher phase of fattening, compared with the control group. The results of the study performed by ABDEL-RAHMAN et al. (2012) showed that the supplementation of different probiotics in drinking water significantly increased BW and improved FCR from the 3rd week of age to the end of the 6 week experiment.

During the experimental period there was no mortality of chickens in any of the groups. The best production results of fattening, expressed as EPI, were achieved by the chickens in the E2 group and it was significantly higher $(331)(\mathrm{P}<0.05)$ compared to group C (320). The high value of the EPI was certainly influenced by the lack of mortality of chickens during the experiment. Our results are in agreement with the study by KAVAZOVIĆ et al. (2009) who reported that the best EPI (310) was obtained in chickens treated by an experimental probiotic compared to the control (302) and a group treated with the probiotic Probios $^{\circledR}$ (301). TIMMERMAN et al., 2006, reported that in four trials (three conducted in production and one in experimental conditions) the EPI was higher by 1.84 to $8.70 \%$ for probiotic-treated chickens. The highest EPI (321) was found in chickens in the experiment carried out under experimental conditions.

The effects of the test mixture or probiotics on the carcass and carcass yield of broilers at 42 days of age are shown in Table 3.

Table 3. Carcass and carcass yield at $42^{\text {nd }}$ day of age

\begin{tabular}{|l|c|c|c|c|c|}
\hline Parameter & $\mathrm{C}$ & $\mathrm{E}_{1}$ & $\mathrm{E}_{2}$ & $\mathrm{SD}$ & P value \\
\hline Carcass, g & $1674.2^{\mathrm{b}}$ & $1709.7^{\mathrm{a}}$ & $1724.5^{\mathrm{a}}$ & 37.9 & 0.04 \\
\hline Carcass yield, \% & 70.66 & 70.71 & 71.16 & 0.72 & 0.336 \\
\hline
\end{tabular}

abc - Means within the same row with no common superscript differ significantly $(\mathrm{P}<0.05)$; SD - Pooled standard deviation of all means within the same row combined with One-way ANOVA procedure in Minitab 17 (Minitab, Inc. 2014).

Groups E1 and E2 presented significantly higher $(\mathrm{P}<0.05)$ carcass weight compared to group C. The carcass yields were $71.16 \%, 70.71 \%$ and $70.66 \%$ for groups E2, E1 and $\mathrm{C}$, respectively. The benefits of probiotics on carcass weight have been reported by 
A. Kavazović et al..: Effects of test mixture and commercial probiotic on broilers growth performance

other authors (BOOSTANI et al., 2013; SALEHIMANESH et al., 2016). A significant increase $(\mathrm{P}<0.05)$ in $\mathrm{BWG}, \mathrm{FCR}$ and carcass weight of chickens was observed in birds fed flavomycin and dry yeast at the end of a 6-week period (DENLI et al., 2003) but nonsignificant changes for carcass yield were observed $(\mathrm{P}>0.05)$.

\section{Conclusion}

The results obtained in this study indicate that the addition of the test mixture (L. acidophillus, inactivated baker's yeast, C vitamin, lactose and glucose) and the commercial probiotic Probios ${ }^{\circledR}$ was effective in improving the growth performance of broilers (BWG, FCR, carcass weight and EPI).

\section{References}

ABD-EL RAHMAN, A., H. H. KAMEL, W. M. AHMED, O. S. H. MOGODA, A. H. MOHAMED (2012): Effect of Bactocell ${ }^{\circledR}$ and Revitilyte-Plus as probiotic food supplements on the growth performance, hematological, biochemical parameters and humoral immune response of broiler chickens. World Applied Sciences Journal 18, 305-316.

DOI: 10.5829/idosi.wasj.2012.18.03.63247

APATA, D. F. (2008): Growth performance, nutrient digestibility and immune response of broiler chicks fed diets supplemented with a culture of Lactobacillus bulgaricus. J. Sci Food Agric. $88,1253-1258$.

DOI: $10.1002 /$ jsfa.3214

BAI, S. P., A. M. WU, X. M. DING, Y. LEI, J. BAI, K. Y. ZHANG, J. S. CHIO (2013): Effects of probiotic-supplemented diets on growth performance and intestinal immune characteristics of broiler chickens. Poultry Sci. 92, 663-670.

DOI: $10.3382 /$ ps.2012-02813

BOOSTANI, A., H. R. MAHMOODIAN FARD, A. ASHAYERIZADEH, M. AMINAFSHAR (2013): Growth performance, carcass yield and intestinal microflora population of broilers fed diets containig tepax and yogurt. Braz. J. Poult. Sc. 15, 1-6.

DOI: /10.1590/S1516-635X2013000100001

CORRIER, D. E., A. JR. HINTON, R. L. ZIPRIN, R. C. BEIER, J. R. DE LOACH (1990): Effect of dietary lactose on cecal ph, bacteristatic volatile fatty acids, and Salmonella typhimurium colonization of broiler chicks. Avian Dis. 34, 617-625.

DENLI, M., K. CELIK, and F. OKAN (2003): Comparative effects of feeding diets containing Flavomycin, Bioteksin-L and Dry Yeast (Saccharomyces cerevisiae) on broiler performance. J. Appl. Anim. Res. 23, 139-144.

DOI:10.1080/09712119.2003.9706415

EDDENS, F.W. (2003): An alternative for antibiotic use in poultry - Probiotics. Braz. J. Poult. Sc. 5, 75-97.

DOI: $10.1590 / \mathrm{S} 1516-635 \mathrm{X} 2003000200001$ 
A. Kavazović et al.: Effects of test mixture and commercial probiotic on broilers growth performance

ECKERT, N. H., J. T. LEE, D. HYATT, S. M. STEVENS, S. ANDERSON, P. N. ANDERSON, R. BELTRAN, G. SCHATZMAYR, M. MOHNL, D. J. CALDWELL (2010): Influence of probiotic administration by feed or water on growth parameters of broilers reared on medicated and nonmedicated diets. J. Appl. Poult. Res. 19, 59-67.

DOI: 10.3382/japr.2009-00084

FAO (2009): Guidelines for the evaluation of probiotics in food.

FULLER, R. (1999): Probiotics for Farm Animals. In Probiotics: A Critical Review. (Tannock G. W., Ed.) Horizon Scientific Press, Wymondham, England, pp. 15-22.

GADDE, U., W. H. KIM, S. T. OH, H. S. LILLEHOJ (2017): Alternatives to antibiotics for maximizing growth performance and feed efficiency in poultry: a review. Animal Health Research Reviews, Cambridge University Press, 1-20.

DOI:10.1017/S1466252316000207

HRNČAR, C., J. WEISL, S. MINDEK, J. BUJKO (2014): Effect of probiotic addition in drinking water on body weight and body measurements of broiler chickens. Animal Sciences and Biotechnologies 47, 249-253.

JIN, L. Z., Y. W. HO, N. ABDULLAH, S. JALALUDIN (2000): Digestive and bacterial enzyme activities in broilers fed diets supplemented with Lactobacillus cultures. Poultry Sci. 79, 886-891. DOI:10.1093/ps/79.6.886

KAVAZOVIĆ, A., Š. SIVRO, E. REŠIDBEGOVIĆ, F. ALIBEGOVIĆ-ZEČIĆ, A. GAGIĆ (2004): Influence of probiotics on production results in fattening chicks of "Cobb". Krmiva 46, 4, 135 139 (in Croatian).

KAVAZOVIĆ, A., A. GAGIĆ, E. REŠIDBEGOVIĆ, F. ALIBEGOVIĆ-ZEČIĆ, T. GOLETIĆ, Ć. CRNKIĆ, A. KUSTURA, A. SOFTIĆ (2009): Effect of probiotics on production results of broiler chicks. Stočarstvo 63, 121-133.

MAHFUZ, S. U., M. J. NAHAR, C. MO, Z. GANFU, L. ZHONGJUN, S. HUI (2017): Inclusion of probiotic on chicken performance and immunity: A Review. Int. J. Poult. Sci. 16, 328-335. DOI: 10.3923/ijps.2017.328.335

MANAFI, M., M. HADEYATI, S. MIRZAIE (2018): Probiotic Bacillus species and Saccharomyces boulardii improve performance, gut histology and immunity in broiler chickens. S. Afr. J. Anim. Sci. 48, 379-389.

DOI:10.4314/sajas.v48i2.19

MINITAB release 17 (2014): Statistical software for windows. Minitab Inc, USA.

NAYEBPOR, M, P. FARHOMAND, A. HASHEMI (2007): Effects of different levels of direct fed microbial (Primalac) on growth performance and humoral immune response in broiler chickens. J. Anim. Vet. Adv. 6, 1308-1313.

NIKPIRAN, H., M. TAGHAVI, A. KHODADADI, S. S. ATHARI (2013): Influence of probiotic and prebiotic on broiler chickens performance and immune status. J. Nov. App. Sci. 2, 256-259.

Vet. arhiv 89 (6), 873-883, 2019 
A. Kavazović et al..: Effects of test mixture and commercial probiotic on broilers growth performance

ONIFADE A. A., A. A. ODUNSI, G. M. BABATUNDE, B. R. OLREDE, E. MUMA (1999): Comparison of the supplemental effects of Saccharomyces cerevisiae and antibiotics in low protein and high fibre diets fed to broiler chickens. Arch Tierernahr, 52, 29-39.

DOI: $10.1080 / 17450399909386149$

POURAKBARI, M., A. SEIDAVI, L. ASADPOUR, A. MARTÍNEZ (2016): Probiotic level effects on growth performance, carcass traits, blood parameters, cecal microbiota, and immune response of broilers. An. Acad. Bras. Cienc. 88, 1011-1021.

DOI: 10.1590/0001-3765201620150071

SALEHIMANESH, A., M. MOHAMMADI, M. ROOSTAEI-ALI MEHR (2016): Effect of dietary probiotic, prebiotic and synbiotic supplementation on performance, immune responses, intestinal morphology and bacterial populations in broilers. J. Anim. Physiol. An. N. 100, 694700 .

DOI: $10.1111 /$ jpn.12431

SALIM, H. M., H. K. KANG, N. AKTER, D. W. KIM, J. H. KIM, M. J. KIM, J. C. NA, H. B. JONG, H. C. CHOI, O. S. SUH, and W. K. KIM (2013): Supplementation of direct-fed microbials as an alternative to antibiotic on growth performance, immune response, cecal microbial population, and ileal morphology of broiler chickens. Poultry Sci. 92, 2084-2090.

DOI: $10.3382 /$ ps.2012-02947

TALEBI, E., M. KHADEMI (2011): Combination effects of ascorbic acid and glucose in drinking water on the broiler performance under acute heat stress. Int. J. Appl. Biol. Pharm. 2, 92-96.

TIMMERMAN, H. M., A. VELDMAN, E. VAN DE ELSEN, F. M. ROMBOUTS, A. C. BEYNEN (2006): Mortality and growth performance of broilers given drinking water supplemented with chicken-specific probiotics. Poultry Sci. 85, 1383-1388.

DOI: $10.1093 / \mathrm{ps} / 85.8 .1383$

TOGHYANI, M., S. K. MOSAVI, M. MODARESI, N. LANDY (2015): Evaluation of kefir as a potential probiotic on growth performance, serum biochemistry and immune response in broiler chicks. Anim. Nutr 1, 305-309.

DOI: 10.1016/j.aninu.2015.11.010

TORRES-RODRIGUEZ, A., S. E. HIGGINS, J. L. S. VICENTE, A. D. WOLFENDEN, G. GAONA-RAMIREZ, J. T. BARTON, G. TELLEZ, A. M. DONOGHUE, B. M. HARGIS (2007): Effect of lactose as a prebiotic on turkey body weight under commercial conditions. J. Appl. Poultry Res. 16, 635-641.

DOI:10.3382/japr.2006-00127

VICENTE, J. L., L. AVINA, A, TORRES-RODRIGUEZ, B. HARGIS, G. TELLEZ (2007.): Effect of Lactobacillus spp. - based probiotic culture product on broiler chicks performance under commercial conditions. Int. J. Poult. Sci 6, 154-156.

DOI: 10.3382/japr.2009-00012 
A. Kavazović et al.: Effects of test mixture and commercial probiotic on broilers growth performance

Received: 15 April 2019

Accepted: 28 July 2019

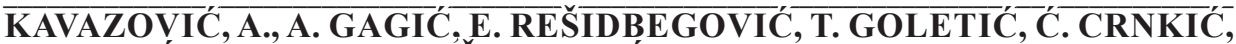 A.SOFTIĆ,A.KUSTURA, E.ŠATROVIĆ: Učinci testne mješavine i komercijalnog probiotika na proizvodna svojstva brojlera. Vet. arhiv 89, 873-883, 2019. \\ SAŽETAK}

Cilj istraživanja bio je analizirati učinke dodatka testne mješavine ili probiotika u vodi za piće na proizvodna svojstva brojlerskih pilića. Ukupno 240 jednodnevnih pilića Cobb 500 podijeljeno je u tri skupine, i to po osam ponavljanja u svakoj skupini (10 pilića u svakom ponavljanju). Kontrolna skupina pilića (K) bila je bez tretmana. Pilići u pokusnoj skupini E1 tretirani su komercijalnim probiotikom Probios ${ }^{\circledR}$, a pilići u pokusnoj skupini E2 testnom mješavinom (kultura Lactobacillus acidophilus, inaktivirani pekarski kvasac, vitamin C, laktoza i glukoza) pripremljenom prema vlastitoj recepturi. Tretman pilića provodio se prva tri dana života i trodnevno, pri cijepljenju pilića, u vodi za piće. Pokus je trajao 42 dana. Tijekom pokusnog razdoblja pilići su dobivali hranu i vodu ad libitum. Analizirani su tjelesna masa, konzumacija hrane, prirast tjelesne mase, konverzija hrane, masa trupa, randman mesa i proizvodni indeks (European Production Index, EPI). Dodavanjem testne mješavine znakovito je povećana tjelesna masa pilića u dobi od 21,35 i 42 dana $(\mathrm{P}<0,05)$. $\mathrm{U}$ istom je razdoblju dodatkom probiotika Probios ${ }^{\circledR}$ tjelesna masa pilića neznakovito poboljšana u usporedbi s kontrolnom skupinom. Konverzija hrane znakovito je poboljšana u dobi od 21 i 35 dana u skupinama E1 i E2, ali bez učinka tretmana na kraju tova. Probiotski tretman nije utjecao na konzumaciju hrane. Pilići tretirani testnom mješavinom ili probiotikom ostvarili su znakovito veću masu trupa na kraju tova. Dobiveni rezultati pokazuju da dodatak testne mješavine ili probiotika poboljšava prirast tjelesne mase, konverziju hrane, masu trupa i proizvodni indeks (EPI).

Ključne riječi: brojlerski pilići; testna mješavina; probiotik; proizvodni pokazatelji; trup 
